\title{
Political Relations between Albania and France 1945- 1990
}

\author{
Arshela Arapi \\ Ministry of Foreign Affairs, \\ Paris, France
}

Doi: 10.2478/mjss-2018-0109

\section{Abstract}

This paper focuses on the relations between Albania and France in the period 1945-1990 in the political optics, and aims to evaluate the dynamics of this cooperation, pointing to the different intensity at different times during dictatorship, byhilosophical demagoguery of the Albanian party and the identification of collaborative priorities extended over 20 years. Albanian - French cooperation spread in all fields. Since our country was still unconfirmed as a state, it needed the experience of other countries. France was a kind of guide to our country, as it was a developed country. Albania also linked with France by some traditional and conjunctural elements. France regarded Albania as very important, and considered it as an opportunity to expand its economy and improve its situation. France needed the mineral resources of Albania. In general, our relations with France has been normal and were concretized in several areas of mutual interest, such as trade and culture. In various speeches, the Albanian leadership has expressed the desire to strengthen more these relations on the basis of the recognized principles of equality, non-interference and mutual benefit. But at certain times, there was also anxiety, and in July 1984, there was a regress of state relations.

Keywords: France, collaboration, convention, strategy

\section{Introduction}

In the framework of the complex historical evaluation of the diplomatic policy of the Albanian country, the relationships, with the European countries in general and those of the Western Europe especially, hold a great importance.

All conditions have been provided for a real and critical evaluation of the entire diplomacy of Albanian country under the dictatorship circumstances. The maturity time of all archive documentation provides a great chance that facilitates the complex study of the Albanian Diplomacy. Furthermore, the actual opportunities which are connected to the rapid process of Albania opening up to other countries, the facilities provided by globalization and all the advanced technologies, all these are available for each and every one of us to study, analyze, juxtapose, evaluate and re-evaluate - all of the above mentioned will benefit history in general, and diplomacy particularly.

In this context, one of the most potential countries, in western politics and that of the world politics is France and the relationship with it is of a special interest to Albania.

The close relationship to France and the actual opportunities made possible by having worked in the Embassy of the Albanian Republic in Paris, were important factors that made possible the development of this vast and complex study.

This study aims at giving a full picture of the dual diplomatic relationship between The Republic of Albania and the Republic of France during 1945-1998. The main objective of this study is to highlight the diplomatic engagement between Albania and France in the political, institutional, educational and cultural, military and economic field during the dictatorship and post-dictatorship period. 


\section{Material and Methods}

The archives from the Albanian Foreign Affairs Ministry and those of the French one have provided a rich material which ensured the highlighting of important facts needed to carry out analysis and historical interpretations in the political, economic, cultural and military fields as well as those of human rights.

The comparison of both archival resources is a very valuable contribution in favor of the quality of work, representing at the same time two viewpoints of the assessment of bilateral diplomatic realities, and to be accurate this is an important and crucial point which guides the point of interpretation of facts from an adequate and realistic position. It is precisely this position that is of interest, thus avoiding any possibility of subjectivism regarding the reminiscences of dictatorship taboos, with serious consequences on foreign policy.

The development and format of this study was made possible by coordinating the same facts and trials of both sides, and by making the opposition of the French side in the important areas of bilateral exchanges as well as by referring to the "principled" positions which were often harsh on the Albanian side. As a matter of fact, the archive materials of the French Foreign Affairs Ministry served well in many directions; firstly, they are references of a special importance in relation to the historical truth, centuries-old diplomatic experience, contributions to world policy-making, the generosity and indulgence of a great nation, giving sustained support and etatist culture in the governance of a country, even when it is a small country.

Retrospective, moderation in judgement and rational interpretation, selected research methodology, constitute a triad where the function of processing the data taken into consideration constitutes the main elements of the study.

Applying a unique and integral methodology in relation to the archival performance of the two countries, as well as the great opportunity of comparing these two practices- one functioning within the limits of the dictatorship of the most fanatic leaders and the other being positioned at the top of world democracy with special contributions to the construction of the most democratic European countries which in turn monitor the democracy of the countries in the continent concerned- was an opportunity that was exploited with great dedication and responsibility.

\section{Results}

\subsection{The intentions of France towards Albania}

France was a great imperialist power and any principle it used to proclaim foreign policy, this policy remained of a great power, of an imperial power. However, with the exception of the 1912-1920 period, French imperialism had no intentions in the past to extend its dominion in Albania, nor to make Albania an area of its influence. Adriatic had so far not been a concern of the French Strategy (Dedijer Vladimir 1949). Also, in economic terms, France had no interest in investing in Albania. The exploitation of a mine like that of the Selenica greenhouse at the time of the Ottoman empire, which belongs to the beginnings of the expansion French imperialism investments in the orient, ceased to give satisfaction to the new Italian imperialism (Fishta Iliaz \& Toçi Veniamin 1983). France's most obvious interests in Albania were those of the cultural field, such as the presence of the French language in our country. This is was very necessary for that time, as in the Western European countries and the Mediterranean ones, French language was ranked right after English where it had played the dominant role in the past, and when in the Eastern European countries French was ranked not only after Russian, but also after English.

Another interest of France was the political one. As above mentioned, because this country always aimed at occupying the world as a great power, as well as not wanting other powers to enter its influence zones, and to influence the growth of centrifugal forces with the Soviet bloc countriesFrance had set as a principle of its foreign policy, the policy of national independence.

The independent policy of our country and especially its exiting from the Warsaw pact corresponded to some of the concerns of the French government, so France was interested in exposing this policy and looking at it with sympathy. The French Government was interested in the 
Albanian stand of being an example for the Mediterranean countries, Eastern Europe ones, third world countries, and even for the Common Market countries that had close ties with America, or with England. There were two other major points for France's political interests towards Albania:

1. First of all, due to the friendship that the Republic of Albania had with the Republic of China, France had great interests in approaching China for world balance as far as the political plan was concerned, and for the huge Chinese market as far as the economic plan was concerned.

2. Secondly, as a Mediterranean country with a traditionally Muslim majority and of which the Arab countries were fond of, France had an interest of drawing its attention to Albania because of its Arab policy.

In the first time period that pertained to 1924-1946-1949 it was noted that the diplomatic relations between the Albanian and French states were already established. They originated in 1922. The policy of France towards Albania and Albanian issues is dictated by its imperial interests in various forms according to different circumstances and conditions. The issues of borders can also be included here.

In 1933 the Albanian government, evaluating its bad foreign trade situation, thought of taking coercive measures for those countries that disagreed with the interests of both sides (Amery Julian 1948). This could lead to the rejection of the establishment of various trade relations between these countries, and this phenomenon would in turn bring problems both for our country and other countries (Fishta lliaz \& Ziu Mihal 1999).

In the second time period, from 1951-1958, there was an improvement of the situation between our country and France. In July 1957, our country as considered as a strategic place in the prism of the capitalist world. With the consolidation of the communist system in Albania, the Albanian state was seen as an isolated country from the world. The embracing of the communist system after the Second World War was considered by Europe as a total detachment from the West.

In the third time period, from 1959 to 1962, France was the only capitalist power with which Albania had diplomatic relations.

The work of Albanian Legation in Paris consisted of:

- Following up on the relationship between Albania and France, as well as the legation relations with accredited representatives in France. These relationships consisted in establishing the best, fair, regular, and profitable relationships between Albania and France.

This has also been proved in the established relations, for example: in the various participations made by Albania in France or by the French delegations in Albania, even though these were not very pronounced and it was appreciated by both the Albanian and French side. We should not forget the participation of other European countries as well.

- Providing information of the situation in France. Since our country was still not consolidated as a state, it needed the experience of other countries and France was some kind of guide for our country, being that it had a developed status.

- The information regarding the situation in France:

- Makes possible the pursuit of press and propaganda and particularly how our country's propaganda in France is being promoted.

Special attention is given to the work with colonies political negotiations. In the other time period, from 1963 to 1966, there was an awareness of the French side to improve the situation between the two countries (Griffith, W.E. 1963). On April14, 1964, French Minister Pier Gors was requested to be present in our Ministry of Foreign Affairs in Tirana and it was suggested that the French government look at the issue of establishing diplomatic representations of both countries in Tirana and in Paris at the Embassy level. On May 12, the French minister stated that France agreed to this. In this way it was achieved that the diplomatic representations of the two countries were established in the rank of embassies (Archive of Ministry of Foreign Affairs, Albania, 1974, d 317 p. 12).

- In the fifth time period, from 1967 to 1979, there was a decrease in the level of cooperation between these two countries.

France made attempts for Albania to take part in the European Security Conference, and our 
country expected other attempts to be made from France. In recent years, France wanted to expand its relationship with Albania, and it also wanted to normalize our country's relations with neighboring countries. During 1973, the French government made the first attempt to establish relations between the two countries slightly above the level of ambassadors where it always used to be. In 1970, several initiatives were undertaken in the relationship between Albania and France, such as the draft of veterinary convention (Archive of Ministry of Foreign Affairs, Albania, 1974, d 317 p. 12).

In the other time period, from 1980 to 1986, located between two sides of Europe that was divided by the Iron Curtain, Albania had remained in miserable neutrality in the 80 -s. This happened when both sides of Europe, benefiting from all the ups and downs phases of Cold War, had occasionally carried out trans-European communications and cooperation.

Albanian diplomacy remained more or less in the same parameters with Eastern Europe.

The numerous and profound ideological and political disputes that were inherited since the early 1960-s continued to maintain solid, limited-time cooperation and associating at all times with mistrust and skepticism. The Albanian foreign policy continuously declared to never cease the war against the modern revisionism that had captured these countries, a war that Albania considered a priority and immutable (Bethel, Nicholas 1984). The relations of Albania with the European powers were very complicated, excluding France which was among the first European powers to recognize Enver Hoxha's regime immediately after World War 2, and had established diplomatic relationship with it. During the Cold War France did neither endorse nor strongly oppose Enver Hoxha's regime. France's lack of support for Tirana regime was dictated by two factors: first, from the very Stalinist character of Tirana regime, which was incompatible with French democracy and its values, and which was strongly opposed by public opinion and French media continuously. Secondly, from France's continued priority of its foreign policy towards Yugoslavia from the time of De Gaul to Miteran, i.e during the entire Cold War period.

Albania and France were also linked by some traditional and conjunctural elements. France had traditionally been present very early in Albania's history. However, in the economic field with France in the 1980-s, the cooperation in the field of hydropower technology was of special interest (Archive of Ministry of Foreign Affairs, Albania, 1984, d 147 p. 24).

France cared for the creation of a French-speaking intellectual elite in Albania for the years to come.

\section{Conclusion}

In general, our relations with France have been normal and they have been concretized in several areas of mutual interest, such as trade and culture.

In July 1984, there was an alienation in the state relations that manifested itself with the withdrawal of their ambassador to Paris for some time and in not inviting representatives from our country to their national day ceremony.

So in conclusion, we can say that the performance of the political and legal relations between Albania and France has been good but almost in the same line. We can say that there has been a more or less similar development.

\section{References}

Amery Julian (1948). Sons of the Eagle. A study in Guerilla War, London, MacMilan and Co.

Archive of Ministry of Foreign Affairs, Albania (1974, d 317 p. 12)

Archive of Ministry of Foreign Affairs, Albania (1984, d 147 p. 24)

Bethel, Nicholas (1984) The Great Betrayal, Hoddes \& Stoughton Publisher, London, Bland

Dedijer Vladimir (1949) Jugoslovensko-albanski odnosi (1939-1948), Beograd

Fishta Iliaz \& Toçi Veniamin (1983) Gjendja ekonomike e Shqipërisë në vitet 1912-1944, prapambetja e saj, shkaqet dhe pasojat, botim i Institutit të Historisë së Akademisë së Shkencave, Tiranë.

Fishta Iliaz \& Ziu Mihal (1999) Ndërhyrja e kapitalit të huaj dhe roli i saj për pushtimin e Shqipërisë (1936-1939), Tiranë

Griffith, W.E. (1963) Albania and Sino-Soviet Rift, Cambridge, Massachusetts 